\title{
Response of Chemical Fertilizers and Micronutrients on Yield, Yield Attributes and Economics under Maize-Wheat Cropping System
}

\author{
Ashok Kumar*, R. K. Pathak, A. K. Sachan, Hanuman Prasad Pandey, \\ Manish Rao and Lalit Krishna Yadav \\ Department of Soil Science and Agricultural Chemistry, Chandra Shekhar Azad University of \\ Agriculture and Technology, Kanpur-208002(U.P.), India \\ *Corresponding author
}

\section{A B S T R A C T}

\section{Keywords}

Wheat, Maize,

Nitrogen,

Phosphorus,

Potassium, Sulphur,

Zinc, Iron and

Azotobactor

\section{Article Info}

Accepted:

10 November 2019

Available Online:

10 December 2019
A field experiment entitled Response of chemical fertilizers and micronutrients on yield, yield attributes and economics under maize-wheat cropping system was conducted at Pot house of the Department of Soil Science and Agricultural Chemistry, Chandra Shekhar Azad University of Agriculture and Technology, Kanpur for two consecutive year of 201617 in kharif season and2017-18 in rabi seasons in micro plots. The objectives of the experiment were (i) to find out most suitable dose of nutrients for grain and stalk/straw yield of maize and wheat, (ii) to find out benefit cost ratio of maize and wheat crops. The investigation consisted of 9 treatments viz. Control, $\mathrm{N}_{(150)}, \mathrm{N}_{(150)}+\mathrm{P}_{(75)}, \mathrm{N}_{(150)}+\mathrm{P}_{(75)}+\mathrm{K}$ ${ }_{(75)}, \mathrm{N}_{(150)}+\mathrm{P}_{(75)}+\mathrm{K}_{(75)}+\mathrm{S}_{(60)}, \mathrm{N}_{(150)}+\mathrm{P}_{(75)}+\mathrm{K}_{(75)}+\mathrm{Zn}_{(5)}, \mathrm{N}_{(150)}+\mathrm{P}_{(75)}+\mathrm{K}_{(75)}+\mathrm{S}_{(60)}+\mathrm{Zn}_{(5)}$, $\mathrm{N}_{(150)}+\mathrm{P}_{(75)}+\mathrm{K}_{(75)}+\mathrm{S}_{(60)}+\mathrm{Zn}_{(5)}+\mathrm{Fe}_{(10)}$ and $\mathrm{N}_{(150)}+\mathrm{P}_{(75)}+\mathrm{K}_{(75)}+\mathrm{S}_{(60)}+\mathrm{Zn}_{(50)}+\mathrm{Fe}_{(10)}+\mathrm{Az}$. which were replicated four times in randomised block design (RBD). Maize ( $c v$-Azad Kamal) and wheat ( $c v$. PBW-343) were taken as test crops. The results revealed that the significant improvement in the physical properties (Bulk density, Hydraulic conductivity and Water stable aggregates) and chemical properties like cation exchange capacity and total organic carbon content of the soil were recorded by silty clay loam in texture, neutral in reaction ( $\mathrm{pH} 7.8$ ), medium in organic carbon $(0.40 \%)$ with $180,10.11$ and $170.0 \mathrm{~kg} \mathrm{ha}^{-1}$ of available N, P and K, respectively. Nine treatment combinations were replicated four times in RBD. Surface $(0-15 \mathrm{~cm})$ and subsurface $(15-30 \mathrm{~cm})$ soil samples taken after the harvest of wheat $(r a b i, 2017-18)$ were analysed for $\mathrm{pH}$, organic carbon, cation exchange capacity, available N, P and K using standard analytical methods. Besides, different fractions of N, P, K, S, Zn and Fe were also determined in the soil samples taken after the wheat harvest (2017-18) and the composite soil samples drawn from adjacent fallow plots. Further increase in grain yield was observed by addition of P. Application of $\mathrm{K}$ with $\mathrm{N}$ and $\mathrm{P}$ fertilizers did not improve the crop yield significantly compared to $150 \%$ nitrogen but further addition of $\mathrm{S}, \mathrm{Zn}$ and $\mathrm{Fe}$ to NPK fertilizers improved the grain yield. Application of 150:75:75\% NPK and combination with $\mathrm{S}, \mathrm{Zn}, \mathrm{Fe}$ and $\mathrm{Az}$ produced the highest average crop yield of maize ( $33.22 \mathrm{q} / \mathrm{ha})$ and wheat $(59.26 \mathrm{q} / \mathrm{ha})$. These treatments also provided significant improvement in yield attributes of major and micronutrients by the crops. Incorporation of the zinc along with $150: 75: 75 \% \mathrm{NPK}$ fertilizers gave the maximum benefit-cost ratio and sustained the soil productivity of the maize-wheat cropping system. 


\section{Introduction}

Soil is the key natural resource and soil quality is the integrated effect of management on most soil properties that determine crop productivity and sustainability. A significant decline in soil quality has occurred worldwide through adverse changes in its physical, chemical and biological properties and contamination by inorganic and organic chemicals. In the past century, about 2 billion of the 8.7billion ha of agricultural land, permanent pastures, and forests and woodlands have been degraded (Arshad and Martin, 2002). Green revolution has brought about spectacular increase in food grain production in the Indo-Gangetic plain of India, continuous use of NPK fertilizers has remarkably increased production but simultaneously developed secondary and micronutrient deficiencies due to restricted use of organic manures. There is an apprehension that the use of chemical fertilizer over the years may impair the soil health. In continuous cropping, use of imbalanced nutrient (N or NP alone) through chemical fertilizers without organic manure resulted in reduction in the desired level of crop productivity (Tiwari et al., 2002; Panwar, 2008). Growing of crops one after another without giving due consideration to nutrient requirements has resulted in decline in soil fertility (Ghosh et al., 2003). There commended dose of NPK fertilizers alone does not sustain productivity under continuous intensive cropping system (Yaduwanshi 2003) whereas inclusion of organic manures improves physical properties (Mandal et al., 2003), the biological soil status, soil fertility and crop yields (Mandal et al., 2003). Stagnationor decline in yield of crops has been observed in many cropping systems in many parts of the country, due to nutrient depletion, soil structure deterioration, imbalanced use of plant nutrients, acidification and suboptimal addition of micronutrients and fertilizers to soil. It is also, well established that chemical fertilizers or micronutrients alone cannot sustain the desired levels of crop production under continuous cropping as observed in many long term fertilizer experiments (Singh and Wanjari, 2013).

Agricultural sustainability is influenced by a number of factors, particularly soil quality. Understanding soil quality is very important as it directly influences crop production (Statish et al., 2016). Soil quality research has focused on the linkages among management practices and observable soil characteristics, soil processes and performance of soil functions. Soil quality assessment has been suggested as an effective tool for evaluating sustainability of soil and crop management practices (Hussain et al., 1999). Soil quality assessment is purpose oriented and site-specific (Karlen et al., 1994). Soil quality cannot be measured directly but must be inferred from measuring changes in its attributes or attributes of ecosystem referred to as indicators (Sharma et al., 2008).

Maize-wheat is the third most important cropping system after rice-wheat and rice-rice in India, and is grown on about 1.80 million ha each year (Jat et al., 2011). It is also prevalent cropping system adopted in uplands of Uttar Pradesh. Increasing crop productivity, reducing production costs and improving environmental quality are the three inter linked components determining the sustainability of cropping system.

\section{Materials and Methods}

A field experiment was conducted at Pot house of the Department of Soil Science and Agricultural Chemistry, Chandra Shekhar Azad University of Agriculture and Technology, Kanpur for two consecutive year of 2016-17 in kharif season and2017-18 in rabi seasons in micro plots. The investigation consisted of 9 treatments viz. Control, $\mathrm{N}_{(150)}$, 
$\mathrm{N}_{(150)}+\mathrm{P}_{(75)}, \mathrm{N}_{(150)}+\mathrm{P}_{(75)}+\mathrm{K}_{(75)}, \mathrm{N}_{(150)}+\mathrm{P}$ ${ }_{(75)}+\mathrm{K}_{(75)}+\mathrm{S}_{(60)}, \mathrm{N}_{(150)}+\mathrm{P}_{(75)}+\mathrm{K}_{(75)}+\mathrm{Zn}_{(5)}, \mathrm{N}$ ${ }_{(150)}+\mathrm{P}_{(75)}+\mathrm{K}_{(75)}+\mathrm{S}_{(60)}+\mathrm{Zn}_{(5)}, \mathrm{N}_{(150)}+\mathrm{P}_{(75)}+\mathrm{K}$ ${ }_{(75)}+\mathrm{S}_{(60)}+\mathrm{Zn}{ }_{(5)}+\mathrm{Fe}{ }_{(10)}$ and $\mathrm{N}_{(150)}+\mathrm{P}_{(75)}+\mathrm{K}_{(75)}$ $+\mathrm{S} \quad{ }_{(60)}+\mathrm{Zn} \quad{ }_{(50)}+\mathrm{Fe} \quad{ }_{(10)}+\mathrm{Az}$ which were replicated four times in randomized block design (RBD). Maize ( $c v$-Azad Kamal) and wheat ( $c v$. PBW-343) were taken as test crops. The soil of experimental farm was silty clay loam in texture, neutral in reaction $(\mathrm{pH} \mathrm{7.8),}$ medium in organic carbon $\left(4.0 \mathrm{~g} \mathrm{~kg}^{-1}\right)$ with $180,10.11$ and $170.0 \mathrm{~kg} \mathrm{ha}^{-1}$ of available $\mathrm{N}, \mathrm{P}$ and $\mathrm{K}$, respectively.

Nine treatment combinations were replicated four times in RBD. Surface $(0-15 \mathrm{~cm})$ and subsurface $(15-30 \mathrm{~cm})$ soil samples taken after the harvest of wheat (rabi, 2017-18) were analysed for $\mathrm{pH}$, organic carbon, cation exchange capacity, available N, P and $\mathrm{K}$ using standard analytical methods. Besides, different fractions of N, P, K, S, Zn and Fe were also determined in the soil samples taken after the wheat harvest (2017-18) and the composite soil samples drawn from adjacent fallow plots. Productivity of maize (2016-17) and wheat (2017-18) was also recorded.

\section{Results and Discussion}

\section{Maize}

\section{Number of cobs plant ${ }^{-1}$}

Table 1 indicated that the number of cobs plant $^{-1}$ was takes important role of yield production. The application of $\mathrm{N}(150)+\mathrm{P}$ ${ }_{(75)}+\mathrm{K}_{(75)} \quad+\mathrm{S} \quad{ }_{(60)}+\mathrm{Zn} \quad{ }_{(50)}+\mathrm{Fe} \quad{ }_{(10)}+\mathrm{Az} \quad$ was obtained maximum number of cobs plant ${ }^{-1}$ as compared to control which was 26.3 and 15.6 percent higher during first and second year. Its ranged varied from 1.09 to 1.48 during first year and 1.29 to 1.53 during second year under control to $\mathrm{N}_{(150)}+\mathrm{P}(75)+\mathrm{K}_{(75)}+\mathrm{S}_{(60)}+\mathrm{Zn}$ ${ }_{(50)}+\mathrm{Fe}{ }_{(10)}+\mathrm{Az}$, respectively. Similar results have been collaborated with Itnal and Palled
(2001), Ma et al., (2007) and Owla et al., (2015).

\section{Number of grains $\operatorname{cob}^{-1}$}

The number of grains $\operatorname{cob}^{-1}$ (Table 1) was increased with increasing doses of fertilizers and it's varied from 114.25 to 19.76 during first year and 14.31 to 19.95 during second year. The number of grains $\mathrm{cob}^{-1}$ was obtained significantly maximum with the application of $\mathrm{N}_{(150)}+\mathrm{P}{ }_{(75)}+\mathrm{K}_{(75)}+\mathrm{S}{ }_{(60)}+\mathrm{Zn}{ }_{(50)}+\mathrm{Fe}{ }_{(10)}+\mathrm{Az}$ which was $28 \%$ higher over control as per mean basis. In addition of $\mathrm{S}, \mathrm{Zn}$ and $\mathrm{Fe}$ with 150:75:75 NPK increased higher number of grains $\mathrm{cob}^{-1}$ as compared to alone 150:75:75 NPK which was $12.43 \%$ lower than combined application. It helps in chlorophyll synthesis and plays an important role in $\mathrm{N}$ metabolism thereby resulting into increased uptake of $\mathrm{N}$ by the plants. These results are in close conformity to the findings of Nanjappa et al., (2001), Wagh (2002) and M. Ayub et al., (2002).

\section{Cob length and cob width}

Results of cob length presented in Table 1 indicated that cob length and width provide suitable place to adjustment for grains setting which will directly affected to yield productivity. The effects of nutrients were responded similar in respect of cob length and width during both of the years. The cob length and width was recorded significantly maximum with the application of $\mathrm{N}(150)+\mathrm{P}$ ${ }_{(75)}+\mathrm{K}_{(75)}+\mathrm{S}{ }_{(60)}+\mathrm{Zn}{ }_{(50)}+\mathrm{Fe}{ }_{(10)}+\mathrm{Az}(22.9$ and $3.87 \mathrm{~cm}$, respectively) which was significantly superior over all the nutrient management. All the treatments responded higher cob length and width in comparison to control. When micronutrients sulphur, zinc and iron combined with $150 \mathrm{~N}$ : $75 \mathrm{P}: 75 \mathrm{~K}$ enhanced $9.04 \%$ cob length and width over control. This might be due to all micro nutrient provide essential component to increase both 
parameters. Similar results have also been reported by Singh and Brar (2006) and Jena et al., (2013).

\section{Test weight}

The test weight represented in Table 1 as weight of 100 grain in gram varied from 20.31 to 32.44 and 20.90 to 33.08 in control and $\mathrm{N}$ ${ }_{(150)}+\mathrm{P}_{(75)}+\mathrm{K}_{(75)}+\mathrm{S}{ }_{(60)}+\mathrm{Zn}_{(50)}+\mathrm{Fe}_{(10)}+\mathrm{Az}$ during first and second year, respectively. This treatment gave $37 \%$ higher test weight over control. This indicated that nutrient application in balanced proportion resulted in enhancing the process of grain setting and filling process and production of maize grain. This might be due to combined application initiates the activity absorption and photosynthesis during grain formation. Similar results have been reported by Sahoo and Mahapatra (2004) and Rashid and Iqbal (2012).

\section{Yield}

The yield data reported in Table 1. Among the application of $\mathrm{N}_{150}$ to $150: 75: 75 \mathrm{NPK}$ the grain yield was enhanced about 20 percent. In addition 150:75:75 NPK added with S or Zn alone or combined $\mathrm{S}+\mathrm{Zn}$ caused significantly increased grain yield $7 \%$ and $4 \%$ over alone application of Zn and S with NPK Further, Combined application of $\mathrm{S}, \mathrm{Zn}$ and $\mathrm{Fe}$ with 150:75:75 NPK, 51.16\% higher over control treatment in respect of grain yield.

During second year, the grain yield was ranged between 15.76 and $33.23 \mathrm{q} \mathrm{ha}^{-1}$ with general mean $24.49 \mathrm{q} \mathrm{ha}^{-1}$. Among $\mathrm{N}_{150}$ to 150:75:75 NPK levels, 150:75:75 NPK levels gave significantly higher yield over $\mathrm{N}_{150}$ to tune about $19.23 \%$ in grain yield. The micro nutrients viz. $\mathrm{S}, \mathrm{Zn}$ and $\mathrm{Fe}$ added with 150:75:75 NPK level enhanced $52.57 \%$ grain yield over control. The alone micro nutrient $\mathrm{S}$ or $\mathrm{Zn}$ or $\mathrm{S}+\mathrm{Zn}$ with $150: 75: 75$ NPK level, the $\mathrm{N}_{(150)}+\mathrm{P}_{(75)}+\mathrm{K}_{(75)}+\mathrm{S}_{(60)}+\mathrm{Zn}_{\text {(5) }}$ gave significantly 7 and 4 percent higher over $\mathrm{N}$ ${ }_{(150)}+\mathrm{P}_{(75)}+\mathrm{K}_{(75)}+\mathrm{S}_{(60)}$ and $\mathrm{N}_{(150)}+\mathrm{P}_{(75)}+\mathrm{K}$ ${ }_{(75)}+\mathrm{Zn}$ (5). The highest yield attributes of maize crop i.e., number of cobs plant ${ }^{-1}$, number of grain $\mathrm{cob}^{-1}$, cob length and cob width as well as test weight obtained with the application of treatment $9\left(\mathrm{~N}_{(150)}+\mathrm{P}_{(75)}+\mathrm{K}_{(75)}\right.$ $\left.+\mathrm{S}_{(60)}+\mathrm{Zn}{ }_{(50)}+\mathrm{Fe}{ }_{(10)}+\mathrm{Az}\right)$ during both year. These results are in close conformity to the findings of Zhang et al., (2011) and Almeida H.J. et al., (2015).

\section{Wheat}

\section{Number of grains plant ${ }^{-1}$}

The number of grains plant ${ }^{-1}$ was takes important role of yield production and presented in Table 2. The application of $\mathrm{N}$ ${ }_{(150)}+\mathrm{P}_{(75)}+\mathrm{K}_{(75)}+\mathrm{S}_{(60)}+\mathrm{Zn}_{(50)}+\mathrm{Fe}_{(10)}+\mathrm{Az}$ was obtained maximum number of grains plant ${ }^{-1}$ as compared to control which was 8.83 and 8.84 percent higher during first and second year. Its ranged varied from 42.23 to 46.32 during first year and 42.26 to 46.36 during second year under control to $\mathrm{N}_{(150)}+\mathrm{P}_{(75)}+\mathrm{K}_{(75)}+\mathrm{S}_{(60)}+\mathrm{Zn}$ ${ }_{(50)}+\mathrm{Fe}{ }_{(10)}+\mathrm{Az}$, respectively. The application of 150:75:75 NPK was $2.47 \%$ higher over alone $150 \mathrm{~N}$. Similar results have been collaborated with Itnal and Palled (2001), Ma et al., (2007) and Owla et al., (2015).

\section{Test weight}

Results on Table 2 revealed that the test weight was increased with increasing doses of fertilizers and it's varied from 29.93 to $33.49 \mathrm{~g}$ during first year and 30.26 to $33.51 \mathrm{~g}$ during second year. The number of test weight was obtained significantly maximum with the application of $\mathrm{N}_{(150)}+\mathrm{P}_{(75)}+\mathrm{K}_{(75)}+\mathrm{S}_{(60)}+\mathrm{Zn}$ ${ }_{(50)}+\mathrm{Fe}{ }_{(10)}+\mathrm{Az}$ which was $10.63 \%$ and $9.69 \%$ higher over control during both the year. 
Int.J.Curr.Microbiol.App.Sci (2019) 8(12): $931-939$

Table.1 Effect of different treatment on yield and yield attributes along with benefit-cost ratio of maize crop during both of the year

\begin{tabular}{|c|c|c|c|c|c|c|c|c|c|c|c|c|c|c|}
\hline \multirow[t]{2}{*}{$\begin{array}{l}\text { Treatments } \\
\text { combination }\end{array}$} & \multicolumn{2}{|c|}{$\begin{array}{l}\text { No. of cob } \\
\text { plant }^{-1}\end{array}$} & \multicolumn{2}{|c|}{$\begin{array}{l}\text { No. of grains } \\
\text { cob }^{-1}\end{array}$} & \multicolumn{2}{|c|}{$\begin{array}{l}\text { Cob length } \\
\text { (cm) }\end{array}$} & \multicolumn{2}{|c|}{ Cob width $(\mathrm{cm})$} & \multicolumn{2}{|c|}{ Test weight (g) } & \multicolumn{2}{|c|}{ Grain yield (q/ha) } & \multicolumn{2}{|c|}{ B:C ratio } \\
\hline & $\begin{array}{c}2016- \\
17\end{array}$ & $\begin{array}{c}2017 \\
-18\end{array}$ & $\begin{array}{c}2016- \\
17\end{array}$ & $\begin{array}{c}2017 \\
-18\end{array}$ & $\begin{array}{c}2016 \\
-17\end{array}$ & $\begin{array}{c}2017- \\
18\end{array}$ & 2016-17 & 2017-18 & 2016-17 & $\begin{array}{c}2017- \\
18\end{array}$ & $\begin{array}{c}\text { 2016- } \\
17\end{array}$ & 2017-18 & 2016-17 & 2017-18 \\
\hline Control & 1.09 & 1.29 & 14.25 & 14.31 & 13.42 & 14.62 & 3.51 & 3.53 & 20.31 & 20.90 & 15.24 & 15.76 & 1.08 & 1.14 \\
\hline $\mathbf{N}_{(\mathbf{1 5 0})}$ & 1.29 & 1.39 & 15.86 & 15.79 & 13.96 & 14.91 & 3.56 & 3.58 & 21.87 & 22.04 & 19.99 & 21.12 & 1.36 & 1.46 \\
\hline $\mathbf{N}_{(150)}+P_{(75)}$ & 1.31 & 1.39 & 16.53 & 16.93 & 14.68 & 15.72 & 3.62 & 3.63 & 23.63 & 24.05 & 24.37 & 25.82 & 1.51 & 1.62 \\
\hline $\mathbf{N}_{(150)}+\mathbf{P}_{(75)}+K_{(75)}$ & 1.32 & 1.40 & 17.21 & 17.56 & 14.79 & 15.87 & 3.67 & 3.69 & 24.95 & 25.61 & 24.95 & 26.15 & 1.47 & 1.57 \\
\hline $\mathrm{N}_{(150)}+\mathrm{P}_{(\mathbf{7 5 )}}+\mathrm{K}_{(75)}+\mathrm{S}$ & 1.34 & 1.43 & 17.98 & 18.97 & 15.83 & 16.53 & 3.72 & 3.74 & 26.84 & 26.57 & 25.56 & 26.81 & 1.41 & 1.51 \\
\hline $\mathrm{N}_{(150)}+\mathrm{P}_{(75)}+\mathrm{K}_{(75)}+\mathrm{Zn}$ & 1.35 & 1.42 & 18.82 & 18.21 & 16.94 & 16.53 & 3.75 & 3.78 & 26.23 & 27.34 & 26.28 & 27.58 & 1.50 & 1.60 \\
\hline $\begin{array}{c}\mathrm{N}_{(150)}+\mathrm{P}_{(75)}+\mathrm{K}_{(75)}+\mathrm{S} \\
{ }_{(60)}+\mathrm{Zn}_{(5)}\end{array}$ & 1.39 & 1.48 & 19.46 & 19.56 & 17.31 & 17.68 & 3.79 & 3.81 & 27.74 & 28.24 & 27.41 & 28.71 & 1.43 & 1.52 \\
\hline $\begin{array}{c}\mathrm{N}_{(150)}+\mathrm{P}_{(75)}+\mathrm{K}_{(75)}+\mathrm{S} \\
{ }_{(60)}+\mathrm{Zn}_{(5)}+\mathrm{Fe}_{(10)}\end{array}$ & 1.44 & 1.52 & 19.87 & 19.87 & 20.48 & 22.14 & 3.82 & 3.85 & 31.15 & 32.25 & 29.93 & 31.63 & 1.48 & 1.59 \\
\hline $\begin{array}{c}\mathrm{N}_{(150)}+\mathrm{P}_{(75)}+\mathrm{K}_{(75)}+\mathrm{S} \\
{ }_{(60)}+\mathrm{Zn} \\
(50)+ \\
+\mathrm{Fe} \\
(10)\end{array}$ & 1.48 & 1.53 & 19.76 & 19.95 & 22.45 & 23.54 & 3.86 & 3.89 & 32.44 & 33.08 & 31.21 & 33.23 & 1.53 & 1.60 \\
\hline $\mathrm{SE}(\mathrm{m})$ & 0.066 & 0.036 & 0.875 & 0.652 & 0.822 & 0.672 & 0.145 & 0.132 & 0.58 & 0.86 & 1.048 & 0.988 & & \\
\hline C.D. $(P=0.05)$ & 0.204 & 0.111 & 2.689 & 2.005 & 2.526 & 2.066 & NS & NS & 1.77 & 2.64 & $\mathbf{3 . 0 7 7}$ & 2.902 & & \\
\hline
\end{tabular}


Table.2 Effect of different treatment on yield and yield attributes along with benefit-cost ratio of wheat crop during both of the year

\begin{tabular}{|c|c|c|c|c|c|c|c|c|}
\hline \multirow[t]{2}{*}{ Treatments combination } & \multicolumn{2}{|c|}{$\begin{array}{l}\text { No. of grains } \\
\text { plant }^{-1}\end{array}$} & \multicolumn{2}{|c|}{ Test weight (g) } & \multicolumn{2}{|c|}{ Grain yield (q/ha) } & \multicolumn{2}{|c|}{ B:C ratio } \\
\hline & 2016-17 & 2017-18 & 2016-17 & 2017-18 & 2016-17 & 2017-18 & 2016-17 & 2017-18 \\
\hline Control & 42.23 & 42.26 & 29.93 & 30.26 & 23.59 & 23.84 & 1.27 & 1.28 \\
\hline $\mathbf{N}_{(\mathbf{1 5 0})}$ & 42.96 & 42.93 & 29.98 & 30.32 & 27.67 & 28.19 & 1.46 & 1.51 \\
\hline $\mathbf{N}_{(150)}+\mathbf{P}_{(75)}$ & 43.56 & 43.59 & 30.44 & 30.62 & 39.38 & 39.41 & 1.89 & 1.94 \\
\hline$N_{(150)}+P_{(75)}+K_{(75)}$ & 44.05 & 44.08 & 30.46 & 30.92 & 43.58 & 43.63 & 1.99 & 2.04 \\
\hline $\mathbf{N}_{(150)}+\mathbf{P}_{(75)}+\mathbf{K}_{(75)}+\mathbf{S}_{(60)}$ & 44.15 & 44.18 & 30.97 & 31.05 & 50.68 & 50.74 & 2.12 & 2.18 \\
\hline $\mathrm{N}_{(150)}+\mathrm{P}_{(75)}+\mathrm{K}_{(75)}+\mathrm{Zn}_{(5)}$ & 45.32 & 45.36 & 31.50 & 31.90 & 54.28 & 54.54 & 2.45 & 2.52 \\
\hline $\mathrm{N}_{(150)}+\mathrm{P}_{(75)}+\mathrm{K}_{(75)}+\mathrm{S}_{(60)}+\mathrm{Zn}$ & 46.08 & 46.12 & 31.76 & 32.15 & 54.84 & 54.86 & 2.27 & 2.34 \\
\hline $\begin{array}{c}\mathrm{N}_{(150)}+\mathrm{P}_{(75)}+\mathrm{K}_{(75)}+\mathrm{S}_{(60)}+\mathrm{Zn} \\
{ }_{(5)}+\mathrm{Fe}_{(10)}\end{array}$ & 46.15 & 46.18 & 32.38 & 32.85 & 55.37 & 55.70 & 2.19 & 2.27 \\
\hline $\begin{array}{c}\mathrm{N}_{(150)}+\mathrm{P}_{(75)}+\mathrm{K}_{(75)}+\mathrm{S}_{(60)}+\mathrm{Zn} \\
(50)+\mathrm{Fe}_{(10)}+\mathrm{Az}\end{array}$ & 46.32 & 46.36 & 33.49 & 33.51 & 58.76 & 59.76 & 2.29 & 2.40 \\
\hline SE(m) & 1.12 & 1.18 & 0.832 & 1.014 & 2.12 & 2.09 & & \\
\hline C.D. $(P=0.05)$ & NS & NS & NS & NS & 6.21 & 6.15 & & \\
\hline
\end{tabular}


In addition of $\mathrm{S}, \mathrm{Zn}$ and $\mathrm{Fe}$ with 150:75:75 NPK increased higher number of test weight as compared to alone 150:75:75 NPK which was $1.75 \%$ lower then combined application on the mean basis. Sulphur, Zinc and iron also enhances the absorption of essential nutrients by increasing CEC of roots. These results are in close conformity to the findings of Nanjappa et al., (2001), Wagh (2002) and Ayub et al., (2002).

\section{Grain yield}

The grain yield was varied from 23.59 and $58.76 \mathrm{q} \mathrm{ha}^{-1}$ with a mean value of $41.17 \mathrm{q} \mathrm{ha}^{-1}$ during 2016-17. Among the application of $\mathrm{N}_{150}$ to $150: 75: 75 \mathrm{NPK}$ the grain yield was enhanced about 35.94 percent over $\mathrm{N}_{150}$. In addition 150:75:75 NPK added with $\mathrm{S}$ or Zn alone or combined $\mathrm{S}+\mathrm{Zn}$ caused significantly increased grain yield $25.83 \%$ over alone application NPK. Further, Combined application of $\mathrm{S}, \mathrm{Zn}$ and $\mathrm{Fe}$ with 150:75:75 NPK, $59.85 \%$ higher over control treatment in respect of grain yield. During second year, the grain yield was ranged between 23.84 and $59.76 \mathrm{q} \mathrm{ha}^{-1}$ with general mean $41.80 \mathrm{q} \mathrm{ha}^{-1}$. Among $\mathrm{N}_{150}$ to 150:75:75 NPK levels, 150:75:75 NPK levels gave significantly higher yield over $\mathrm{N}_{150}$ to tune about $35.38 \%$ in grain yield. The micro nutrients viz. $\mathrm{S}, \mathrm{Zn}$ and Fe added with 150:75:75 NPK level enhanced $60.10 \%$ grain yield over control. The highest yield attributes of wheat crop i.e., number of grains plant ${ }^{-1}$, test and yield obtained with the application of treatment9 $\left(\mathrm{N}_{(150)}+\mathrm{P}_{(75)}+\mathrm{K}_{(75)}\right.$ $\left.+\mathrm{S}_{(60)}+\mathrm{Zn}{ }_{(50)}+\mathrm{Fe}{ }_{(10)}+\mathrm{Az}\right)$ during both year. These results are in close conformity to the findings of Zhang et al., (2011) Almeida et al., (2015) and Liu H. et al., (2016).

\section{Economics}

Benefit: cost ratio range was varied between 1.08 and 1.14 to 1.53 to 1.62 in maize and 1.27 to 1.28 to 2.45 to 2.52 in wheat during first and second year of observations. All the application which was applied over maize and wheat crop increased grain and stover that of enhanced the benefit: cost ratio as compared to control treatment where not applied any nutrient management practices during both of the years. Results in this study are agreement with those of following workers Kachroo and Razdan (2006) and Thirupathi et al., (2016).

There was a significant build-up in available phosphorus and organic carbon, decline in available nitrogen and available potassium through integrated use of inorganics and micro nutrients for the years. Integrated use of inorganics and micro nutrients has sustained the crop yields. On the other hand, use of recommended dose of nutrients through inorganic fertilizers though sustained the yields, but does not improved the soil physical, chemical and microbiological properties to the extent of the combined use of the micro nutrients and inorganics.

\section{References}

Arshad, M.A. and Martin, S. (2002). Identifying critical limits for soil quality indicators in agro-ecosystems. Agriculture, Ecosystems and Environment 88: 153-160.

Ghosh, P.K., Dayal, D., Mandai, K.N, Wanjari, R.H. and Hati, K.M. (2003).Optimization of fertilizer schedules in fallow and groundnut based cropping system and an assessment of system sustainability. Field Crop Research 80: 83-98.

Hussain, I., Olson, K.R., Wander, M.M. and Karlen, D.L. (1999). Adaptation of soil quality indices and application to three tillage systems in southern Illinois. Soil and Tillage Research 50: 237-249.

Karlen, D. L., Wollenhaupt, N,C., Erback, D.C., Berry, E.C., Swan, J.B., Eash, N.S., and Jordakl, J.L. (1994). Crop 
residue effects on soil quality following 10- years of notill corn. Soil and Tillage Research 31:149-167.

Mandal, U.K., Singh, O., Victor, U.S. and Sharma, K.L. (2003). Green manuring: its effect on soil properties and crop growth under rice-wheat cropping system. European Journal of Agronomy 19: 225-237.

Panwar, A.S. (2008). Effect of integrated nutrient management in maize (Zea mays)- mustard (Brassica campestris var. toria) cropping system in mid hills altitude. Indian Journal of Agricultural Sciences 78 (1): 27-31.

Satish, A., Ramachaandrappa, B.K., Shankar, M.A., Srikanth Babu, P.N., Srinivasarao, C.H. and Sharma, K.L. (2016). Long-term effects of organic manure and manufactured fertilizer additions on soil quality and sustainable productivity of fingermillet under a fingermillet-groundnut cropping system in southern India. Soil Use and Management 32: 311-321.

Sharma, K.L., Kusuma Grace, J., Mandal, U.K., Gajbhiye, P.N., Srinivas, K., Korwar, G.R, Bindu, V.H., Ramesh,V., Ram chandran, K. and Yadav, S.K. (2008).Evaluation of long term soil management practices using key indicators and soil quality indices in a semi and tropical Alfisol. Australian Journal of Soil research 46:368-377.

Singh, M. and Wanjari, R.H. (2013). Measures to sustain and restore declined productivity in Alfisols under Long Term Fertilizer Experiments. Indian Journal of Fertilisers 9 (2): 24-32.

Tiwari, A., Diwedi, A.K. and Dikshit, P.R. (2002). Long term influence of organic and inorganic fertilizer on soil fertilization and productivity of soyabean-wheat system in a Vertisol. Journal of the Indian Society of Soil Science 50: 472-475.
Yaduwanshi, N.P.S. (2003). Substitution of inorganic fertilizers by organic manures and the effect on soil fertility in a rice wheat rotation on reclaimed soil in India. Journal of Agricultural Sciences 140: 161- 168.

Itnal, C.J. and Palled, Y.B. (2001). Studies on inter cropping of sunhemp green manuring in hybrid maize. Karnataka J. Agric. Sci., 14 (3): 586-596.

Kachroo. D, and Razdon, R (2006). Growth and yield of wheat as influence by biofertilizer and N. Indian Journal of Agronomy, 15(1): 37-39.

Liu. Rang Gen, Wu. Meiju, Zhou, Min. Chenzheng Ming, Shen. Bl. Yu, Liu, Rg. /Wu. Mj, Zhou, m., Chen, Zm, Shen, By (2002) Influence of different rates and deterioration of nitrogen fertilizers Beijing 1999, No.2, and 2222.

Ma, B.L., Subedi, K.D. and Costa, C. (2007). Comparison of crop based indicators with soil nitrate test for corn nitrogen requirement. Agron. J., 97, 462-471.

Owla, M.L. V., Nepalia, Chouhan, G.S. and Singh, D. (2015). Effect of fertility levels, nutrient sources and weed control on weed dynamics and yield of quality protein maize (Zea mays L.) and relative nitrogen and phosphorus uptake, Indian J. Agron., 60 (2): 267272.

Sahoo, S. C. and Mahapatra, P.K. (2004). Response of sweet corn (Zea maysL.) to nitrogen levels and plant population. Indian J.Agric. Sci., 74 (6): 337-338.

Singh, Dilip and Brar, N.K. (2006). Grain yield, nitrogen uptake and nitrogen use efficiency in wheat as influenced by $\mathrm{N}$ levels under different crop. Environment and Ecology 24 (2): 325332.

Wagh, D. S. (2002). Effect of spacing and integrated nutrient management on growthand yield of sweet corn (Zea 
mays L. saccharata).M.Sc. (Agri) Thesis, Mahatma Phule Krishi Vidyapeeth, Rahuri, dist. Pune (India). Zhang, Huimin, Yang; Xue, Yun, He; Xinhun, $\mathrm{Xu}$, MinGang; Huang, Shamin, Liu; Hua, Wang, BoRen. (2011). Effect of long term potassium fertilization on crop yield, potassium efficiency and balance under wheat - maize rotation in China. Pedosphere.21 (2): 154-163. Jat, M.L., Saharawat, Y.S. and Gupta, R.
(2011). Conservation agriculture in cereal systems of South Asia: nutrient management perspectives. Karnataka Journal of Agricultural Sciences 24:100-105.

Nanjappa, H. V.; Ramachandrappa, B. K. and Mallikarjun, B. O. (2001). Effect of integrated nutrient management on yield and nutrient balance in maize (Zea mays L.).Indian J. Agron., 46(4): 698-701.

\section{How to cite this article:}

Ashok Kumar, R. K. Pathak, A. K. Sachan, Hanuman Prasad Pandey, Manish Rao and Lalit Krishna Yadav. 2019. Response of Chemical Fertilizers and Micronutrients on Yield, Yield Attributes and Economics under Maize-Wheat Cropping System. Int.J.Curr.Microbiol.App.Sci. 8(12): 931-939. doi: https://doi.org/10.20546/ijcmas.2019.812.119 